\title{
Assessment Attributes on Effective Construction Management for Property Developers in Malaysia
}

\author{
AYOB NORIZAM ${ }^{1}$, M.A. MALEK ${ }^{2 *}$ AND I. MOHAMAD ${ }^{3}$
}

\begin{abstract}
Property developers are financially capable of running construction projects. Nevertheless, in Malaysia it was found that many of these construction practitioners failed to provide effective construction management which affected society. The success of a project and its Critical Success Factors (CSFs) are considered as tools to improve the effectiveness of project management. Even though many researchers have conducted studies on CSFs, the use of CSFs has remained ambiguous. The main objective of this study is to validate the proposed assessment attributes obtained from the property developers based on CSFs. A questionnaire survey was conducted to validate this predetermined attributes. Comparison was made with attributes from Project Management Book of Knowledge in order to explore the underlying suitability of the proposed attributes with the study area in terms of climate, economy, etc. Factor Analysis was adopted to investigate the group component relationships. This study focuses on the link between CSFs and the implementation of an effective construction management specifically for property developers in Malaysia.
\end{abstract}

Key words: Critical Success Factors; property developer; assessment; construction industry; Malaysia; management; factor analysis

Malaysia has shown very rapid growth in property and construction since the 1970s. The competition among property developers has created major changes in the construction industries mainly in the design and infrastructure, in order to satisfy the needs of the property buyers. Eventually, the capability of property developers varies. Project management, including the tools, techniques, and knowledge-based practices applied to manage the creation of products and services, is becoming an increasingly accepted and applied discipline across industry sectors (Jugdev et al. 2007). Adoption of project management is used as 'a method' for solving complex organizational problems. Such a viewpoint treats project management as one of the several ways of handling organizational activity. Similar arguments and standpoints are found in numerous project management research texts (Söderlund 2004).

Research on Critical Success Factors (CSFs) in the construction industries were mainly based on theoretical rather than empirical evidences (Khosrowshahi \& Howes 2005). But, what is the extent of expectation that could be obtained from CSFs? The outcome of this study is therefore to determine the measurement arrays as attributes in developing an effective costruction management (CM) assessment for property developer in Malaysia.

\footnotetext{
${ }^{1}$ Civil Engineering Deptartment, Universiti Tenaga Nasional, Jalan Ikram - UNITEN, 43000 Kajang, Selangor, Malaysia

${ }^{2}$ The Institute of Energy, Policy and Research (IEPRe), Universiti Tenaga Nasional, Jalan Ikram - UNITEN, 43000 Kajang, Selangor, Malaysia

${ }^{3}$ Dept of Mathematical Science, Universiti Teknologi Malaysia, 81310 Johor Bahru, Malaysia

* Corresponding author (e-mail: marlinda@uniten.edu.my)
} 


\section{Literature Review}

CSFs has been defined as a tool to identify executive information needs (Rockart 1982). Rockart et al. (1979) identified four prime sources of CSFs in any industry, which are: (1) Structure of the industry: has its own set of CSFs which are dependent on its characteristics; (2) Competitive strategy, industry position and geographic allocation: each organization has its own strategies and strategic plan due to the nature of the industry in which it operates; (3) Environmental factors: the effects of the environment upon the organization behaviour are essential to understand the CSFs; (4) Temporal factors: CSFs changes with the change of the organization priorities, where the areas of activity for success changes and some activities become more critical and others become less critical (Elwakil et al. 2009).

In Managing Information Systems, CSFs examine their existing methodologies, and from time to time, CSFs has been widely used by other industries, including the construction industry. In the construction industry, CSFs are integrated with eight elements that are used as benchmarking parameters which are: structure of industry; competitive strategy; market conditions; political environment; organizational structure; technical applications; employee enhancements and process benchmarking (Rockart 1982; Sanvido et al. 1992; Abraham 2003). Success is defined by Ashley et al. (1987) as 'results much better than expected or normally observed in terms of cost, schedule, quality, safety and participant satisfaction'. The investigation of success factors in construction industries have attracted the interest of many researchers and many studies have been conducted with the aim of providing valuable insights into how to consistently achieve superior results for the projects. Although construction projects are by their nature repetitive activities, each one has its own characteristics and circumstances (Salleh 2009).
Chan (2004) identified five primary CSFs from 44 identified factors, which are: projectrelated factors; project procedures; project management actions; human-related factors and external environment (Yong \& Mustaffa 2011; Doloi et al. 2011) established attributes that relate to schedule and performance, listing 55 attributes that were subsequently grouped into six CSFs and seven Critical Failure Factors. Those factors are project managers' competence, supportive owners, top management monitoring, feedback, and co-ordination. Love et al. (2002) identified 55 attributes and grouped them into five CSFs for public-private partnership projects in the United Kingdom. The five categories were: effective procurement; project implementation ability; government guarantees; favourable economic conditions, and the available financial market. Abraham (2004) identified seven CSFs that influence the success of construction industries which are: competitive strategy; market analysis; political environment; economic environment; technical application; employee/ organizational enhancement and process benchmarking. Saqib (2008) listed the top five CSFs affecting the construction industries in Pakistan, developed from 77 identified factors which are: contractor-related factors; project management factors; procurement-related factors and design team-related factors. Marc Hockins (Stolton \& Leverington 2006) proved that CSFs are the best methodology to develop an executive monitoring system to contain corporate-wide indicators of success (Elwakil et al. 2009). In this study, the function of CSFs is reversed by using attributes obtained from the questionnaire survey conducted.

\section{RESEARCH METHODOLOGY}

In order to achieve the objective of this study, a questionnaire survey was distributed among the practitioners in the construction industry which included government sectors, consultants, property developers, contractors and others (suppliers, manufacturers, planners 
and others.). The questionnaire contained 37 nominated success factors for property developers. It was developed from an extensive literature review and was consolidated by a series of pilot studies conducted in several states of Malaysia.

Five hundred sets of questionnaires were distributed within Malaysia. The distribution was categorized into few regions which consisted of the central region (Selangor and Kuala Lumpur), northern region ((Pulau Pinang, Kedah, Perak and Perlis), eastern region (Kelantan, Terengganu and Pahang), southern region (Negeri Sembilan, Melaka and Johor) and East Malaysia (Sabah and Sarawak). Data were collected and analyzed using Factor Analysis in statistics via SPSS (V.20). The Factor Analysis technique used was Principal Component Analysis (PCA) where effective variables are used to identify the principal factors. This techniques enables a more in-depth understanding of factor grouping techniques to underpin the success measures (Robinson et al. 2005). PCA can also be used for hypothesis testing or in searching for constructs within a group of variables (Sommerville et al. 2004). It is a series of methods for finding clusters of related variables and hence an ideal technique for reducing a large number of items into a more easily understood framework (Norusis 2008). Since the numbers of variables for CSFs for pre-determined attributes were about 37 numbers, Factor Analysis was used in this study, to converge these numbers to make it more reliable.
In order to determine the validity of the questionnaire developed in this study, Cronbach's alpha was tested to provide an accurate estimate of internal consistency and indicates how well the items in the set were correlated to one another (Brown \& Adams 2000). The internal consistency ranges between zero and one. A commonly-accepted rule of thumb is that scores of above 0.70 are considered acceptable (Nunnally 2010). In this study, Cronbach's alpha was computed at 0.791 which indicated that the items were in the form of a scale with reasonable internal consistency reliability.

\section{DATA ANALYSIS AND RESULTS}

\section{Response Rate}

A total of 344 questionnaires were satisfactorily completed, resulting to a total response rate of $68.8 \%$. This is acceptable as according to Takim et al. (2004) and Peansupap et al. (2005); they stated normal response rate in the construction industries for postal questionnaires is approximately between $20 \%$ to $30 \%$. The General Respondent Demographic showed that the majority of the respondents $(48.3 \%)$ were from property developers as shown in Table 1.

The questionnaires were distributed to all practitioners in the construction industries in Malaysia. Based on Table 1, it was found that the highest respondents were property developers $(48.4 \%)$, followed by contractors (20.6\%), consultants $(14.2 \%)$, the government sector $(12.5 \%)$ and others $(4.4 \%)$.

Table 1. Respondent to questionnaire based on General Respondent Demographics.

\begin{tabular}{l|lcccc}
\hline & Type of organization & Frequency & Percent & Valid prcent & Cumulative percent \\
\hline \multirow{7}{*}{ Valid } & Government & 43 & 12.5 & 12.5 & 12.5 \\
& Consultants & 49 & 14.2 & 14.2 & 26.7 \\
& Property developer & 166 & 48.3 & 48.3 & 75.0 \\
& Contractor & 71 & 20.6 & 20.6 & 95.6 \\
& Others & 15 & 4.4 & 4.4 & 100.0 \\
& Total & 344 & 100.0 & 100.0 & \\
\hline
\end{tabular}




\section{Ranking of Critical Success Factors}

The first analysis was performed to rank the nominated factors based on the mean values of the responses. In this study, it was assumed that if two or more factors happen to have the same mean values, then the one with the lowest standard deviation would be assigned as the highest important rank among the nominated factors. In addition, factors with means exceeding or equal to the value of four are recognized as CSFs based on the consensus of the respondents. In this study, 15 factors were identified as CSFs having significant influence on the success of this study. Table 2 shows the ranking of these factors according to the value of their statistical means.
The CSFs identified in this study were largely in line with the findings of other researchers in the field of CSFs. Nevertheless, unlike other studies on CSFs, this study led to the refinement of the assessment attributes that would ensure affective construction management in Malaysia.

\section{Factor Analysis}

In this study, Factor Analysis is used to explore and detect the underlying relationships among the identified CSFs. This statistical technique identifies a relatively small number of factors that can be used to represent relationships among sets of many interrelated variables. Various tests

Table 2. Ranking of success factors based on 'Mean' value.

\begin{tabular}{l|ccc}
\hline \multicolumn{1}{c|}{ Success factors } & Mean & $\begin{array}{c}\text { Standard } \\
\text { deviation }\end{array}$ & Ranking \\
\hline $\begin{array}{l}\text { Construction Manager's organizing skills } \\
\begin{array}{l}\text { All aspects of safety, with particular reference to implementation } \\
\text { of safety programme }\end{array}\end{array}$ & 4.60 & 0.644 & 1 \\
$\begin{array}{l}\text { Monitoring results of specific construction as per required with } \\
\text { relevant quality standards. Identifying ways to eliminate } \\
\text { causes of unsatisfactory }\end{array}$ & 4.43 & 0.752 & 3 \\
$\begin{array}{l}\text { Evaluating overall construction performance on a regular basis } \\
\text { to provide confidence that the constructions as per required } \\
\text { quality standard }\end{array}$ & 4.41 & 0.651 & 4 \\
$\begin{array}{l}\text { Identifying which quality standards are relevant to the } \\
\text { construction and execution as per requirement }\end{array}$ & 4.40 & 0.654 & 5 \\
$\begin{array}{l}\text { Identifying ways to eliminate causes of unsatisfactory } \\
\text { Construction Manager's experience and capabilities with } \\
\text { particular reference to technical, administrative, human } \\
\text { relations and communication skills }\end{array}$ & 4.35 & 0.769 & 6 \\
$\begin{array}{l}\text { Construction Manager's leadership skills } \\
\begin{array}{l}\text { Construction planning processes in design, implementation and } \\
\text { monitoring are as per approved documentation. }\end{array}\end{array}$ & 4.30 & 0.768 & 7 \\
$\begin{array}{l}\text { Developing individual and group skills to enhance construction } \\
\text { performance. }\end{array}$ & 4.27 & 0.607 & 10 \\
$\begin{array}{l}\text { Subdividing major construction deliverables into smaller, more } \\
\text { manageable components }\end{array}$ & 4.25 & 0.667 & 11 \\
$\begin{array}{l}\text { Carrying out the Construction plan by performing the activities } \\
\text { included there in }\end{array}$ & 4.22 & 0.618 & 12 \\
\hline
\end{tabular}


Table 2 (Cont.). Ranking of success factors based on 'Mean' value.

\begin{tabular}{|c|c|c|c|}
\hline Success factors & Mean & $\begin{array}{l}\text { Standard } \\
\text { deviation }\end{array}$ & Ranking \\
\hline Analyzing activity sequences & 4.18 & 0.656 & 13 \\
\hline Estimation of period for each construction stage & 4.17 & 0.611 & 14 \\
\hline Company have their own monetary capabilities before start work & 4.17 & 0.556 & 15 \\
\hline Coordinating changes across the entire construction & 4.15 & 0.763 & 16 \\
\hline $\begin{array}{l}\text { Establish a written scope statement as basis for future } \\
\text { construction decisions }\end{array}$ & 4.14 & 0.687 & 17 \\
\hline $\begin{array}{l}\text { All aspects of safety, with particular reference to safety } \\
\text { monitoring programme }\end{array}$ & 4.13 & 0.759 & 18 \\
\hline $\begin{array}{l}\text { Construction Manager's commitment to meeting cost, schedule, } \\
\text { safety and quality commitment }\end{array}$ & 4.13 & 0.836 & 19 \\
\hline $\begin{array}{l}\text { Defining enhancement steps for opportunities and responses } \\
\text { to threats }\end{array}$ & 4.12 & 1.029 & 20 \\
\hline $\begin{array}{l}\text { All aspects of safety, with particular reference to safety } \\
\text { programme regulations and requirement }\end{array}$ & 4.12 & 0.655 & 21 \\
\hline $\begin{array}{l}\text { Evaluating risks to assess the range of possible construction } \\
\text { outcomes }\end{array}$ & 4.11 & 0.944 & 22 \\
\hline Analyzing activity durations & 4.08 & 0.767 & 23 \\
\hline $\begin{array}{l}\text { Construction Manager's co-ordinating ability and rapport with } \\
\text { owner/owners representatives }\end{array}$ & 4.07 & 0.869 & 24 \\
\hline $\begin{array}{l}\text { Construction Manager's co-ordinating ability and rapport with } \\
\text { contractors/subcontractors }\end{array}$ & 4.07 & 0.729 & 25 \\
\hline $\begin{array}{l}\text { Committed to disburse effective construction process to the } \\
\text { organization throughout the project }\end{array}$ & 4.07 & 0.642 & 26 \\
\hline $\begin{array}{l}\text { Evaluating risks interactions to assess the range of possible } \\
\text { construction outcomes }\end{array}$ & 4.05 & 0.918 & 27 \\
\hline $\begin{array}{l}\text { Developing an approximation (estimate) for the costs of } \\
\text { resources }\end{array}$ & 4.04 & 0.729 & 28 \\
\hline Analyzing activity requirements & 3.97 & 0.799 & 29 \\
\hline Controlling changes to the construction budget & 3.93 & 0.777 & 30 \\
\hline Allocation of overall cost estimation to individual work items & 3.92 & 0.632 & 31 \\
\hline $\begin{array}{l}\text { Responding to changes in risk over the course of the } \\
\text { construction }\end{array}$ & 3.90 & 1.091 & 32 \\
\hline $\begin{array}{l}\text { Developing an approximation (estimate) for the costs of } \\
\text { resources }\end{array}$ & 3.89 & 1.010 & 33 \\
\hline $\begin{array}{l}\text { Determining which risks are likely to affect the construction } \\
\text { and documenting the characteristics of each }\end{array}$ & 3.88 & 0.986 & 34 \\
\hline Determining resources (people, equipment, materials) & 3.75 & 1.058 & 35 \\
\hline Monitoring changes to the construction schedule & 3.73 & 0.998 & 36 \\
\hline Determining quantities & 3.60 & 0.973 & 37 \\
\hline
\end{tabular}


are required for the appropriateness of this method for factor extraction.

In this study, 37 numbers of CSFs were obtained as shown in Table 3 subjected to Factor Analysis using PCA and varimax rotation. PCA is a common method in Factor Analysis. It involves the generation of linear combinations of variables in Factor Analysis so that the variance present in the collected data are considered. This analysis summarizes the variability in the observed data by means of a series of linear combination of 'factors'. Each factor can be viewed as a 'supervariable' comprising a specific combination of the actual variables examined in the survey.
The advantage of this method over other factor analytical approaches is that the mathematical representation of the derived linear combinations avoids the need for the use of questionable causal models (Johnson \& Carter 1993; Shen \& Liu 2003).

\section{Interpretations of the Components Group}

In this study, eight numbers of group components were extracted using varimax rotation Factor Analysis. In accordance to Burgees (2006), based on Factor Analysis output for factor loading the results on all attributes could be defined as very high (0.6), high (0.3), and ignored (less than 0.3) (Kozak-Holland \& Procter 2013).

Table 3. Factor analysis at each group component

\begin{tabular}{|c|c|c|c|c|c|c|c|c|}
\hline & \multicolumn{8}{|c|}{ Group component } \\
\hline & 1 & 2 & 3 & 4 & 5 & 6 & 7 & 8 \\
\hline $\begin{array}{l}\text { Evaluating risks interactions to assess } \\
\text { the range of possible construction } \\
\text { outcomes }\end{array}$ & .957 & & & & & & & \\
\hline $\begin{array}{l}\text { Defining enhancement steps for } \\
\text { opportunities and responses to threats }\end{array}$ & .903 & & & & & & & \\
\hline $\begin{array}{l}\text { Determining resources (people, } \\
\text { equipment, materials) }\end{array}$ & .866 & & & & & & & \\
\hline $\begin{array}{l}\text { Determining which risks are likely } \\
\text { to affect the construction and } \\
\text { documenting the characteristics of each }\end{array}$ & .822 & & & & & & & \\
\hline $\begin{array}{l}\text { Evaluating risks to assess the range of } \\
\text { possible construction outcomes }\end{array}$ & .789 & & & & & & & \\
\hline $\begin{array}{l}\text { Monitoring changes to the construction } \\
\text { schedule }\end{array}$ & .760 & & & & & & & \\
\hline $\begin{array}{l}\text { Developing an approximation (estimate) } \\
\text { for the costs of resources }\end{array}$ & .739 & & & & & & & \\
\hline Determining quantities & .637 & & & & & & & \\
\hline $\begin{array}{l}\text { Developing an approximation (estimate) } \\
\text { for the costs of resources }\end{array}$ & -.409 & & & & & & & \\
\hline Construction Manager's organizing skills & .021 & & & & & & & \\
\hline $\begin{array}{l}\text { Subdividing major construction } \\
\text { deliverables into smaller, more } \\
\text { manageable components }\end{array}$ & -.008 & & & & & & & \\
\hline
\end{tabular}


Table 3 (Cont.). Factor analysis at each group component

\begin{tabular}{|c|c|c|c|c|c|c|c|c|}
\hline & \multicolumn{8}{|c|}{ Group component } \\
\hline & 1 & 2 & 3 & 4 & 5 & 6 & 7 & 8 \\
\hline $\begin{array}{l}\text { Construction planning processes in design, } \\
\text { implementation and monitoring are as } \\
\text { per approved documentation }\end{array}$ & & .677 & & & & & & \\
\hline $\begin{array}{l}\text { Establish a written scope statement as } \\
\text { basis for future construction decisions }\end{array}$ & & .619 & & & & & & \\
\hline Analysing activity sequences & & .582 & & & & & & \\
\hline Construction Manager's leadership skills & & .494 & & & & & & \\
\hline $\begin{array}{l}\text { Construction Manager's experience and } \\
\text { capabilities with particular reference } \\
\text { to technical, administrative, human } \\
\text { relations and communication skills }\end{array}$ & & .107 & & & & & & \\
\hline $\begin{array}{l}\text { All aspects of safety, with particular } \\
\text { reference to safety monitoring } \\
\text { programme }\end{array}$ & & -.095 & & & & & & \\
\hline $\begin{array}{l}\text { Evaluating overall construction } \\
\text { performance on a regular basis } \\
\text { to provide confidence that the } \\
\text { constructions as per required quality } \\
\text { standard }\end{array}$ & & & .636 & & & & & \\
\hline $\begin{array}{l}\text { Identifying which quality standards } \\
\text { are relevant to the construction and } \\
\text { execution as per requirement }\end{array}$ & & & .553 & & & & & \\
\hline Analysing activity requirements & & & .280 & & & & & \\
\hline $\begin{array}{l}\text { Co-ordinating changes across the entire } \\
\text { construction }\end{array}$ & & & .037 & & & & & \\
\hline $\begin{array}{l}\text { Company have their own monetary } \\
\text { capabilities before start work }\end{array}$ & & & & .685 & & & & \\
\hline $\begin{array}{l}\text { Developing individual and group skills } \\
\text { to enhance construction performance }\end{array}$ & & & & .484 & & & & \\
\hline $\begin{array}{l}\text { Construction Manager's co-ordinating } \\
\text { ability and rapport with contractors/ } \\
\text { subcontractors }\end{array}$ & & & & .139 & & & & \\
\hline Analysing activity durations & & & & & .715 & & & \\
\hline $\begin{array}{l}\text { Controlling changes to the construction } \\
\text { budget }\end{array}$ & & & & & -.666 & & & \\
\hline $\begin{array}{l}\text { All aspects of safety, with particular } \\
\text { reference to implementation of safety } \\
\text { programme }\end{array}$ & & & & & .245 & & & \\
\hline $\begin{array}{l}\text { Identifying ways to eliminate causes of } \\
\text { unsatisfactory }\end{array}$ & & & & & -.156 & & & \\
\hline
\end{tabular}


Table 3 (Cont.). Factor analysis at each group component

\begin{tabular}{|c|c|c|c|c|c|c|c|c|}
\hline & \multicolumn{8}{|c|}{ Group component } \\
\hline & 1 & 2 & 3 & 4 & 5 & 6 & 7 & 8 \\
\hline $\begin{array}{l}\text { All aspects of safety, with particular } \\
\text { reference to safety program regulations } \\
\text { and requirement }\end{array}$ & & & & & & .568 & & \\
\hline $\begin{array}{l}\text { Committed to disburse effective } \\
\text { construction process to the organization } \\
\text { throughout the project }\end{array}$ & & & & & & .535 & & \\
\hline $\begin{array}{l}\text { Construction Manager's commitment } \\
\text { to meeting cost, schedule, safety and } \\
\text { quality commitment }\end{array}$ & & & & & & .060 & & \\
\hline $\begin{array}{l}\text { Monitoring results of specific construction } \\
\text { as per required with relevant quality } \\
\text { standards. Identifying ways to eliminate } \\
\text { causes of unsatisfactory. }\end{array}$ & & & & & & & .765 & \\
\hline $\begin{array}{l}\text { Construction Manager's co-ordinating } \\
\text { ability and rapport with owner/owners } \\
\text { representatives }\end{array}$ & & & & & & & .480 & \\
\hline $\begin{array}{l}\text { Allocation of overall cost estimation to } \\
\text { individual work items. }\end{array}$ & & & & & & & .148 & \\
\hline $\begin{array}{l}\text { Responding to changes in risk over the } \\
\text { course of the construction }\end{array}$ & & & & & & & .119 & \\
\hline $\begin{array}{l}\text { Carrying out the Construction plan by } \\
\text { performing the activities included there } \\
\text { in. }\end{array}$ & & & & & & & .069 & \\
\hline $\begin{array}{l}\text { Estimation of period for each construction } \\
\text { stage }\end{array}$ & & & & & & & & .096 \\
\hline
\end{tabular}

Group Component 1: Construction Integration Management (CIM). This includes the processes required to ensure that the various elements of the project are properly co-ordinated. It involves trade-off among competing objectives and alternatives in order to meet or exceed stakeholders' needs and expectations. In this study, nine attributes were integrated in this group component as listed below:

1. Evaluating risks interactions to assess the range of possible construction outcomes

2. Defining enhancement steps for opportunities and responses to threats
3. Determining resources (people, equipment, materials).

4. Determining which risks are likely to affect the construction industry and documenting characteristics

5. Evaluating risks to assess the range of possible construction outcomes

6. Monitoring changes to the construction schedule

7. Developing an approximation (estimate) for the costs of resources

8. Determining quantities; and

9. Developing an approximation (estimate) for the costs of resources. 
Group Component 2: Construction Scope Management (CSM). This includes the processes required to ensure that the project includes all the work required, in order to complete the project successfully. It is primarily concerned with defining and controlling what is not included in the project. In this study, four attributes were integrated in this group component as listed below:

1. Construction planning processes in design, implementation and monitoring are as per approved documentations

2. Establish a written scope statement as basis for future construction decisions

3. Analyzing activity sequences; and

4. Construction manager's leadership skills.

Group Component 3: Construction Quality Management (CQM). This includes the processes required to ensure that the project will satisfy the need for which it is undertaken. It includes all activities on the overall management function that determine the quality policy, objectives, responsibilities and its implementation within the quality system. In this study, two attributes were integrated in this Group Component as listed below:

1. Evaluating overall construction performance on a regular basis to provide confidence that the construction is as per required quality standard; and

2. Identifying which quality standards are relevant to the construction and execution as per requirement.

Group Component 4: Construction Coordination Management (CCM). It includes the processes that ensure cost and human component occupancy will satisfy the necessity of contractors/subcontractors competencies. This relates to progress report, progress payment and others. Attributes under this Group Component are:

1. Companies have their own monetary capabilities before the start of work
2. Developing individual and group skills to enhance construction performance; and

3. The ability of the Construction manager's in co-ordinating rapport with contractors and subcontractors.

Group Component 5: Construction Discrepancies Management (CDM). It relates to managing discrepancies and changes that occur during construction period such as construction activities, budget, time and others. In this study, two attributes were extracted into this Group Component as follows:

1. Analyzing activity durations; and

2. Controlling changes to the construction budget.

Group Component 6: Construction Process Management (CPM). This refers to the ensemble of activities in planning and monitoring of the process performance. In this study, two attributes were integrated in this Group Component as follows:

1. All aspects of safety, particularly on regulations and requirements of safety programe; and

2. Commitment to disburse effective construction process to the organization through the project.

Group Component 7: Construction Deliverability Management (CDM). It refers to the capability of the company to produce the end products as per expectation. In this study, two attributes were extracted in this Group Component as follows:

1. Monitoring results of specific construction trade as per relevant quality standards. Identifying ways to eliminate causes of unsatisfactory products; and

2. The ability of Construction Manager in co-ordinating rapport with client and its representatives. 


\section{CONCLUSION}

This study identified and analyzed the possible assessment attributes on effective CM for property developers in Malaysia. Identification of CSFs were used as measurement tools to determine its effectiveness. The findings of this study were generally in line with the earlier studies performed on CSFs which have been established by other articles in journals. Nevertheless, the findings of this study further enforced the results obtained from CSFs analysis and established the assessment attributes.

In this study, Factors Analysis was used to converge the 37 numbers of identified CSFs into eight groups. Out of the 37 attributes established in this study, 13 were eliminated due to the result obtained from Factor Analysis which was below 0.3 (less impact). It was found that CIM was the highest group component. For future work, the correlation rank at each element of the group components will be further investigated and defined using the Structural Equation Method.

Date of submission: August 2014

Date of acceptance: November 2014

\section{REFERENCES}

Abraham, G. 2003, 'Critical success factors for the construction industry', in Proceedings of Construction Research Congress, pp. 19-21.

Ashley, DB, Lurie, CS \& Jaselskis, EJ 1987, 'Determinants of construction project success', Project Management Journal, vol. 18, no. 2, pp. 69-79, .

Brown, A \& Adams, J 2000, 'Measuring the effect of project management on construction outputs: a new approach', International Journal of Project Management, vol. 18, no. 5, pp. 327-335.

Chan, AP \& Chan, AP 2004, 'Key performance indicators for measuring construction success', Benchmarking: An International Journal, vol. 11, no. 2, pp. 203-221.
Doloi, H, Iyer, K \& Sawhney, A 2011, 'Structural equation model for assessing impacts of contractor's performance on project success', International Journal of Project Management, vol. 29 , no. 6, pp. 687-695.

Elwakil, E, Ammar, M, Zayed, T, Mahmoud, M, Eweda, A \& Mashhour, I 2009, 'Investigation and modeling of critical success factors in construction organizations', in CRC Conference, Seattle, WA.

Johnson, S \& Carter, B 1993, Greener buildings: environmental impact of property. Macmillan.

Jugdev, K, Mathur, G \& Fung, TS 2007, 'Project management assets and their relationship with the project management capability of the firm', International Journal of Project Management, vol. 25 , no. 6 , pp. 560-568.

Khosrowshahi, F \& Howes, R. 2005, 'A framework for strategic decision-making based on a hybrid decision support tools', J. Information Technology in Construction, vol. 10, pp. 111-124.

Kozak-Holland, M \& Procter, C 2013 'Florence cathedral duomo project (1420-1436): learning best project management practice from history', International Journal of Project Management, vol. 214, pp. 675-686.

Love, P, Holt, G, Shen, L, Li, H \& Irani, Z 2002 'Using systems dynamics to better understand change and rework in construction project management systems', International Journal of Project Management, vol. 20, no. 6, pp. 425-436.

Norusis, M 2008, SPSS 16.0 statistical procedures companion. Prentice Hall Press.

Nunnally, JC 2010 Psychometric theory 3E, Tata McGraw-Hill Education.

Peansupap, V \& Walker, DH 2005, 'Factors enabling information and communication technology diffusion and actual implementation in construction organisations', Electronic Journal of Information Technology in Construction, vol. 10, pp. 193-218.

Robinson, HS, Carrillo, PM, Anumba, CJ \& AlGhassani, AM 2005, 'Knowledge management practices in large construction organisations', Engineering, Construction and Architectural Management, vol. 12, no. 5, pp. 431-445.

Rockart, J, Ball, L \& Bullen, C 1982 'Future role of the information systems executive', MIS Quarterly, pp. 1-14. 
Rockart, JF et al. 1982, 'The changing role of the information systems executive: a critical success factors perspective, Sloan Management Review, Massachusetts Institute of Technology.

Salleh, R 2009 'Critical success factors of project management for Brunei construction projects: improving project performance'.

Sanvido, V, Grobler, F, Parfitt, K, Guvenis, M \& Coyle, M 1992, 'Critical success factors for construction projects', Journal of construction engineering and management, vol. 118, no. 1, pp. 94-111.

Saqib, M, Farooqui, RU \& Lodi, S 2008, ‘Assessment of critical success factors for construction projects in Pakistan', in First Int. Conf. on Construction in Developing Countries, Karachi, Pakistan.

Shen, Q \& Liu, G 2003, 'Critical success factors for value management studies in construction', Journal of Construction Engineering and Management, vol. 129, no. 5, pp. 485-491.
Söderlund, J 2004, 'Building theories of project management: past research, questions for the future', International Journal of Project Management, vol. 22, no. 3, pp. 183-191.

Sommerville, J, Craig, N \& Bowden, S 2004, 'The standardisation of construction snagging', Structural Survey, vol. 22, no. 5, pp. 251-258.

Stolton, S \& Leverington, F 2006, Evaluating effectiveness: a framework for assessing the management of protected areas, IUCN.

Takim, R, Akintoye, A \& Kelly, J 2004, 'Analysis of measures of construction project success in Malaysia', in 20th Annual Arcom Conference, Association of Researchers in Construction Management, Heriot Watt University.

Yong, YC \& Mustaffa, NE 2011, 'Clients, consultants and contractors' perception of critical success factors for construction projects in Malaysia', in Proceedings 27th Annual ARCOM Conference, eds C Egbu \& ECW Lou, Association of Researchers in Construction Management, Bristol, UK, pp. 735-744. 